\title{
Breeding for management adaptation in perennial ryegrass (Lolium perenne L). I. Assessment of yield under contrasting cutting frequencies and relationships with leaf morphogenesis components
}

\author{
L Hazard, M Ghesquière *, M Betin \\ INRA, Station d'Amélioration des Plantes Fourragères, F86600 Lusignan, France
}

(Received 15 November 1993; accepted 14 April 1994)

\begin{abstract}
Summary - The potential yield under contrasting cutting frequencies was assessed among 18 diploid or tetraploid varieties of perennial ryegrass and 53 half-sibs progenies from a broad-based polycross. Simultaneously, a survey of the genetic variability of leaf morphogenesis components was carried out among the varieties. Both among varieties and progenies, the yield appeared to be negatively correlated between cutting frequencies and, compared with progenies, varieties were generally found to be more productive under infrequent cutting than under frequent cutting. Diploid and tetraploid varieties were discriminated only by morphogenetic traits related to tiller size and leaf elongation, as expected, with some association with the yield under frequent cutting and tiller density in the plots under the same management. The results suggested that there was a potentially high productivity under frequent cutting which should be considered but seemed to be systematically counterselected by plant breeders, probably due to the procedure of assessment of varieties for registration.
\end{abstract}

Lolium perenne $=$ perennial ryegrass $/$ ploidy $/$ cutting frequency $/$ leaf morphogenesis $/$ genetic progress

Résumé - Amélioration de l'adaptation au mode d'exploitation chez le ray-grass anglais (Lolium perenne L). I. Évaluation du rendement en rythme de coupes contrasté et relation avec les composantes de la morphogenèse foliaire. Le rendement potentiel de 18 variétés diploïdes ou tétraploïdes de ray-grass anglais récemment inscrites au Catalogue français ainsi que pour 53 familles de demi-frères issues d'un polycross à base large a été évalué en rythme de coupes contrasté. Parallèlement, une analyse de la variabilité des composantes de la morphogenèse foliaire a été réalisée sur les variétés. À la fois au niveau des variétés et des descendances, le rendement s'est montré négativement corrélé entre rythmes de coupes mais avec un net avantage des variétés en système fauche et des descendances en rythme de coupes fréquentes. Sur le plan de la morphogenèse, les variétés diploides ont présenté une taille de talle et un allongement foliaire inférieurs à ceux des variétés tétraploides et qui ont été associés à un rendement en coupes fréquentes et à une densité de talles plus élevée. Les résultats font ainsi ressortir qu'il existe un potentiel de productivité supérieur en coupes fréquentes mais qui semble assez systématiquement contre-sélectionné en amélioration, sans doute à cause de la façon dont les variétés sont évaluées pour leur inscription au Catalogue. Bien que la morphogenèse de la plante isolée des variétés ne soit pas apparue étroitement en relation avec l'interaction rendement $x$ rythme de coupes, l'effet de la ploïdie que nous avons observée suggère qu'elle reste une approche déterminante pour améliorer la productivité pour un rythme de coupe donné.

Lolium perenne $=$ ray-grass anglais $/$ ploïdie $/$ fréquence de coupe $/$ morphogenèse $/$ progrès génétique

\footnotetext{
* Correspondence and reprints
} 


\section{INTRODUCTION}

As assessment of adaptation under grazing conditions is long and expensive. Grass varieties are tested under infrequent cutting for official registration in the French recommended list as they are bred in the same way by most seed companies. Even though there may be up to 10 cuts a year in some favourable locations of the network, this never reaches a defoliation frequency of 1 week which simulates continuous grazing (Aldrich and Elliot, 1974; Mazzanti and Lemaire, 1994). Little is known about genetic variability of grazing adaptation among the present varieties of forage grasses although this trait is of major importance for forage species as Lolium perenne which is mainly managed under grazing (Boonman, 1989). The low increase of yield achieved after $30 \mathrm{yrs}$ of breeding in forage grasses (Allerit, 1986; Van Wijk and Reheul, 1990) also emphasizes the need for research into new procedures for assessing genetic variability of productivity and its interactions under contrasting management.

Forage management is characterized by the frequency and the intensity of defoliation and by the developmental stage of the sward at the time of defoliation (Harris, 1978). Defoliation patterns induce therefore a strong effect on the structure of the sward and, consequently, on the yield (Korte and Harris, 1987). Conversely, detailed ecophysiological studies on swards pointed out that management needs to be adjusted to grass morphogenesis and turnover of leaf tissue (Davies, 1977; Lemaire, 1988). Grazing management requires that the sward can easily and rapidly recover an optimum leaf area, while infrequent cutting requires delayed leaf senescence. Using clonal swards selected for highly contrasted morphogenesis, Rhodes (1971) investigated the relationships between sward structure and yield according to defoliation frequency, and those between morphological components and yield (Rhodes, 1969; 1973; 1975). Obviously, differences in morphogenesis between genotypes appeared to be responsible for interactions of yield with defoliation frequency.

As most of the previous studies was carried out either following an ecophysiological approach or from a few genotypes often selected for extreme morphological traits, it is difficult to extend the conclusions for breeding prospects. The objectives of this paper are therefore: (i) to assess the potential yield under frequent cutting of recently registered varieties of perennial rye- grass in comparison with progenies of natural populations; (ii) to show its relationship with the yield as estimated under the usual management followed in the official trials; and (iii) to examine, whether the genetic variability of leaf growth components could control the productivity of varieties and their adaptation, if any, to a given management.

\section{MATERIALS AND METHODS}

Eighteen varieties of either tetraploid or diploid Lolium perenne were chosen as a representative samples of the late-flowering varieties recently registered on the French official list. Altogether, these cultivars were assumed to be significant achievements of forage grass breeding in the EC. In addition, 53 half-sib families were observed plus 4 diploid ('Preference', 'Pacage', 'Vigor', 'Sisu') and 1 tetraploid ('Citadel') varieties used as controls. The progenies were kindly provided by $\mathrm{G}$ Charmet (Station d'Amélioration des Plantes, INRA, Clermont-Ferrand, France) and derived from a polycross of plants sampled from natural lateflowering French populations of Lolium perenne (INRA-ACVF cooperative programme supported by the Ministère de l'Agriculture on the study of genetic resources of perennial ryegrass in France) (Charmet et al, 1990).

\section{Yield under frequent cutting}

\section{Varieties (trial No 1)}

A frequent cutting trial, simulating continuous grazing (Aldrich and Elliot, 1974), was set up using 13 varieties (5 tetraploids and 8 diploids) and 2 controls ('Citadel' and 'Preference'). On March 10, the 15 genotypes were broadcast sown at a $4 \mathrm{~g} / \mathrm{m}^{2}$ density in a 3 randomized block design of forty-five $30 \times 30 \mathrm{~cm}^{2}$ plots. Soil was a sterilized compost and subsequent fertilization and watering were assumed non-limiting regarding leaf growth. From May 27, plots were cut weekly at 3.5 $\mathrm{cm}$ height and were fertilized at a $20 \mathrm{~kg} / \mathrm{ha}$ rate of nitrogen (ammonitrate solution) every 2 weeks. Total dry matter yield of all single plots was determined.

As a steady significant genotype effect started to occur from the 9th cut, yield under infrequent cutting was compared by cumulating yield from cut numbers 9-12 (FCY1). At the end of the experiment (in October), tiller density in the plots (TD) was recorded on a $0-5$ scale.

\section{Progenies (trial No 2)}

A further frequent cutting trial was carried out in the field using the 53 half-sib progenies from the abovementioned polycross, plus 10 varieties (6 diploids and 
4 tetraploids), and 5 controls ('Preference', 'Pacage', 'Vigor', 'Sisu', 'Citadel'). Four other genotypes were included in the trial but were not considered in this paper. On September $271990,1.5 \times 0.75 \mathrm{~m}^{2}$ single plots were broadcast sown at a $4 \mathrm{~g} / \mathrm{m}^{2}$ density in a $3 \mathrm{x}$ $8 \times 9$ rectangular lattice design. The trial was fertilized in March and May 1991 at a $50 \mathrm{~kg} / \mathrm{ha}$ rate of nitrogen (ammonitrate) each time. During spring 1991, plots were mowed every week and harvests of the $0.75 \mathrm{~m}^{2}$ middle part in the plot were dried and weighed.

The cumulative dry matter yield (FCY2) of the 3 cuts on May 23, May 25 and June 121991 was used for comparison with the yield under infrequent cutting.

\section{Yield under infrequent cutting}

\section{Varieties}

To find the relationship of yield between contrasting cutting frequencies among varieties and against the progenies, the yield under infrequent cutting of the varieties (ICY1) was estimated from data provided by the GEVES (Groupe d'Etude des Variétés et des Semences) following the standard procedure of assessment: 5 rows of $1.25 \mathrm{~m}$ per plot, 4 cuts per $\mathrm{yr}$ over 2 yrs, harvest of the 3 middle rows in a plot.

\section{Progenies (trial No 3)}

Yield under infrequent cutting of the 53 half-sib progenies and controls ('Preference', 'Pacage', 'Vigor') were assessed following the GEVES procedure except that plots were 2 rows of $1.25 \mathrm{~m}$ and were completely harvested. The trial was sown in May 1990 in a 3 randomized block design and was fertilized with $60 \mathrm{~kg} / \mathrm{ha}$ of nitrogen in February and May 1991. The yield of the first cut on June 111991 (ICY2) was compared with the cumulative yield under frequent cutting harvested at the same time (FCY2).

\section{Morphogenesis}

\section{Varieties (trial No 4)}

Leaf morphogenesis was studied on the same 15 genotypes (varieties and controls) as used in the frequent cutting trial (No 1) but grown as single plants. Seedlings were first germinated in Petri dishes at $25^{\circ} \mathrm{C}$ on March 24 and then transferred to small pots in a heated greenhouse. On May 19, plants were transplanted into outdoor beds of sterilized compost and were grown under optimum conditions as far as mineral and water supplies were concerned. Plants were therefore not vernalized and all remained vegetative during the recording of morphogenesis. A randomized block design of 20 blocks $\times 15$ plants was used. A first cut at $3 \mathrm{~cm}$ height was done on June 1st. In the following days, one tiller per plant was labelled with a plastic ring once a new entire leaf had emerged. Dates of appearance of the 4 leaves that grew after the cut and dates of ligule emergence of the 3 first leaves were recorded. Once the fourth leaf appeared, the surveyed tillers were harvested and the weight of dry matter of the tillers (DMW) was assessed after a 16-h drying at $80^{\circ} \mathrm{C}$. Plant growth was described by the following traits: adult leaf length (ALL); duration of leaf elongation (LED) as the interval between leaf appearance and ligule emergence which corresponds to the end of the leaf growth (Snyder et al, 1990); and phyllochron $(\mathrm{PHY})$ as the interval between the appearance of 2 successive leaves. Leaf elongation rate (LER) and number of growing leaves per tilier (NGL) were estimated as the ratio ALLLED and LED/PHY, respectively. As growth of the 3 successive leaves per tiller was spread over $30 \mathrm{~d}$, LED, LER, and PHY of each leaf were first weighted by the sum of the daily mean temperatures $\left({ }^{\circ} \mathrm{C}\right)$ and then averaged for each single plant as ALL and DMW.

\section{Statistics}

Multivariate analyses of variance were performed following the appropriate statistical model: block + ploidy + genotype within ploidy (trial No 1 and 4); block + sub-block within block + genotype (trial No 2); and block + genotype (trial No 3). $F$ tests of genotype effect and ploidy effect were done against error and genotype mean squares, respectively. Relationships between morphogenetic traits (trial No 4), tiller density (trial No 1) and yield under frequent cutting (trial No 1) or infrequent cutting (GEVES) were analyzed through within-ploidy genotypic correlations at $13 \mathrm{df}$, as well as through principal components analysis on genotypic means of the same variates and using FCY1 and ICY1 as additional variates.

\section{RESULTS}

Increasing the cutting frequency led to a decrease in the yield of varieties. Thus, the annual yield reached 12 t DM under infrequent cutting and was only 6.8 t DM under frequent cutting. If we consider the cumulative yield under frequent cutting from cuts No 9-12 (FCY1), significant differences occurred between varieties although no effect of the ploidy level was found (tables I and II). The 2 levels of ploidy overlapped widely when yield under both managements was plotted but showed a negative correlation $(-0.721, P<0.01)$ among varieties (fig 1). The same pattern was found among progenies of natural populations with a lower yield under frequent cutting than under infrequent cutting and a negative correlation of $-0.386(P<0.01)$. The error and genotypic coefficient of variation remained of similar 
Table I. Means and ranges for analysis of variance of yield under contrasting cutting frequencies and leaf morphogenesis components observed on 18 tetraploid or diploid varieties, 53 progenies of natural populations and 5 controls of perennial ryegrass.

\begin{tabular}{|c|c|c|c|c|c|c|c|c|c|c|c|}
\hline & & \multicolumn{9}{|c|}{ Mean } & \multirow[t]{4}{*}{ Range } \\
\hline & & \multirow[t]{3}{*}{ Total } & \multirow{3}{*}{$\begin{array}{l}\text { Progenies } \\
\text { (2n) }\end{array}$} & \multicolumn{2}{|c|}{ Varieties } & \multicolumn{5}{|c|}{ Controls } & \\
\hline & & & & \multirow[t]{2}{*}{$2 n$} & \multirow[t]{2}{*}{$4 n$} & \multicolumn{4}{|c|}{$2 n$} & \multirow{2}{*}{$\frac{4 n}{\text { Citadel }}$} & \\
\hline & & & & & & Preference & Pacage & Vigor & Sisu & & \\
\hline \multirow[t]{2}{*}{ Trial No 1: } & FCY1 (tha) & 1.33 & - & 1.37 & 1.26 & 1.53 & - & - & - & 1.06 & $1.06-1.67$ \\
\hline & TD & 3.00 & - & 3.35 & 2.40 & 2.83 & - & - & - & 1.83 & $1.83-3.83$ \\
\hline Trial No 2: & FCY2 (t/ha) & 1.61 & 1.66 & 1.47 & 1.33 & 1.34 & 1.76 & 1.74 & 1.56 & 1.62 & $0.89-2.09$ \\
\hline Trial No 3: & ICY2 (tha) & 8.54 & 8.37 & $10.12^{\star}$ & $10.57^{\star}$ & 9.76 & 9.09 & 8.77 & $10.88^{*}$ & $10.82^{*}$ & $6.61-10.87$ \\
\hline \multirow[t]{6}{*}{ Trial No 4: } & $\mathrm{ALL}(\mathrm{mm})$ & 210 & - & 198 & 228 & 186 & - & - & - & 198 & $181-242$ \\
\hline & NGL & 1.32 & - & 1.32 & 1.32 & 1.35 & - & - & - & 1.32 & $1.26-1.36$ \\
\hline & $\operatorname{LED}\left({ }^{\circ} \mathrm{C} \cdot \mathrm{d}\right)$ & 186 & - & 185 & 188 & 176 & - & - & - & 184 & $172-200$ \\
\hline & $\operatorname{LER}\left(\mathrm{mm} /{ }^{\circ} \mathrm{C} \cdot \mathrm{d}\right)$ & 1.14 & - & 1.09 & 1.22 & 1.06 & - & - & - & 1.17 & $1.00-1.30$ \\
\hline & $\mathrm{PHY}\left({ }^{\circ} \mathrm{C} \cdot \mathrm{d}\right)$ & 143 & - & 142 & 144 & 137 & - & - & - & 135 & $128-155$ \\
\hline & $\mathrm{DMW}(\mathrm{g})$ & 1.27 & - & 1.05 & 1.61 & 0.96 & - & - & - & 0.97 & $0.81-1.84$ \\
\hline
\end{tabular}

* Estimated from data provided by GEVES.

Table II. F-test analysis of variance of yield under contrasting cutting frequencies and leaf morphogenesis components observed on 18 tetraploid or diploid varieties, 53 progenies of natural populations and 5 controls of perennial ryegrass.

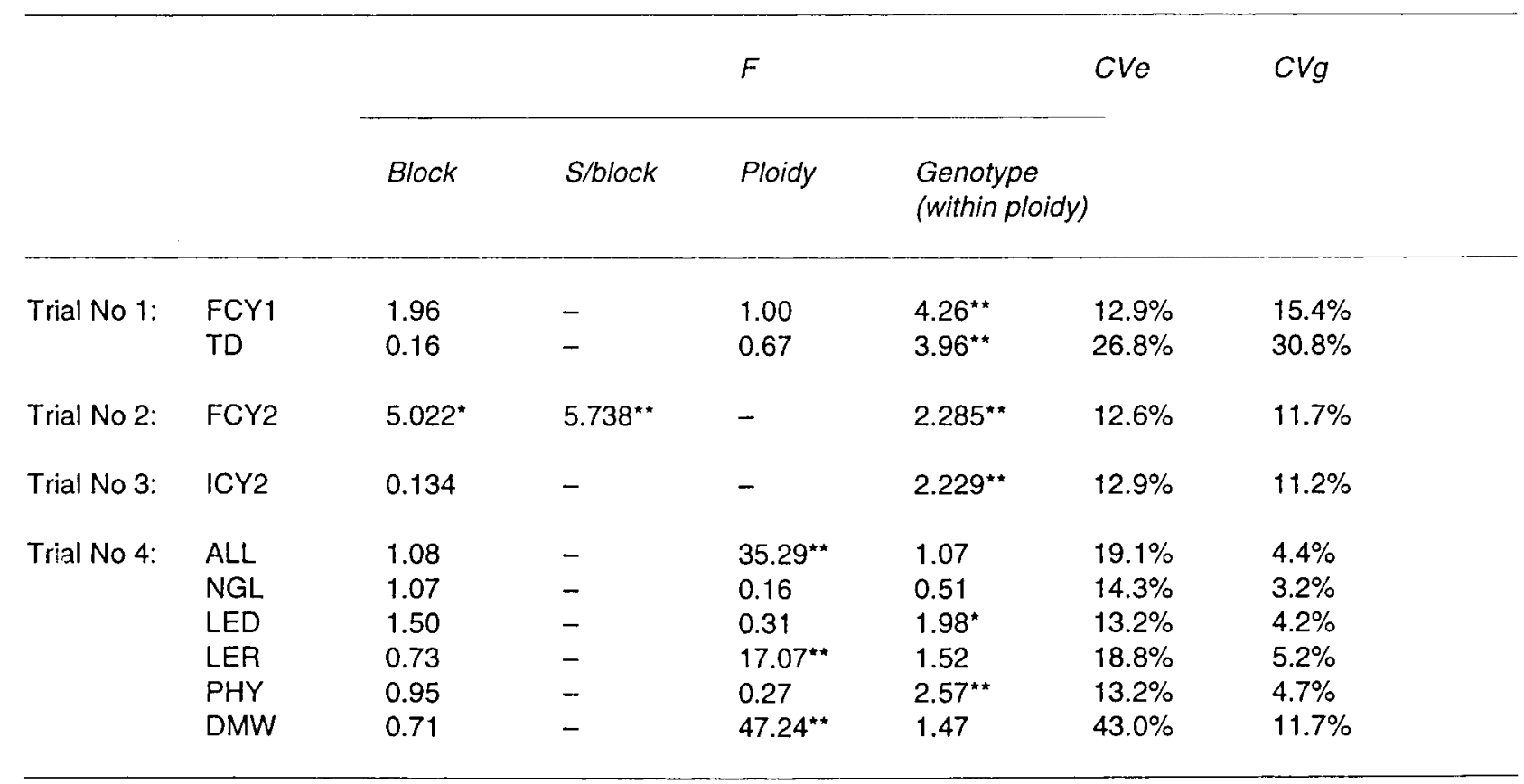

* $P<0.05 ; * * P<0.01 ; C V e$ : error coefficient of variation; CVg: genotypic coefficient of variation. 
a

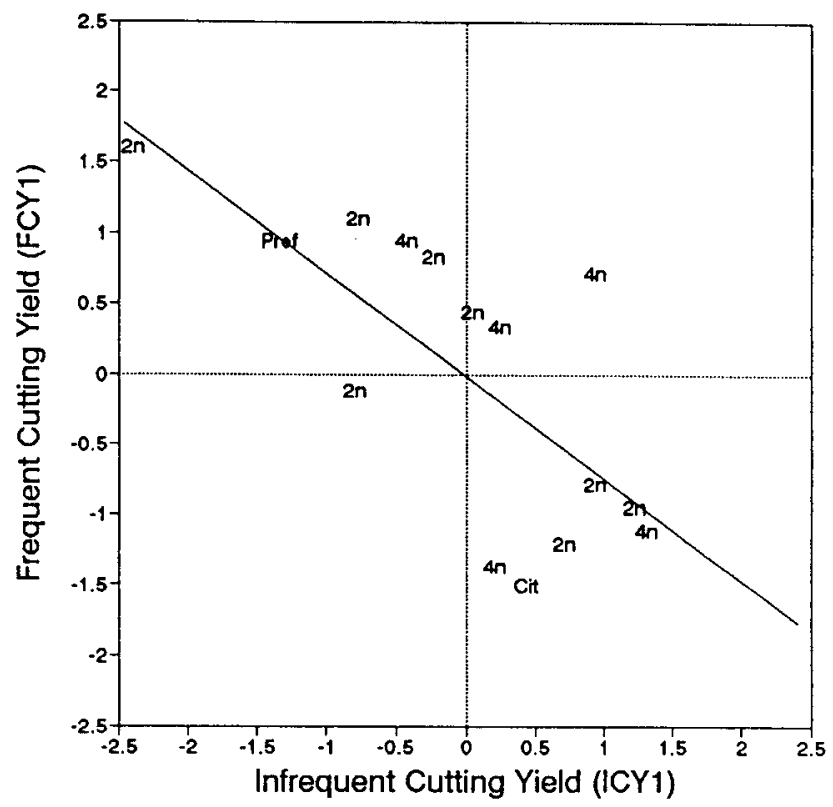

b

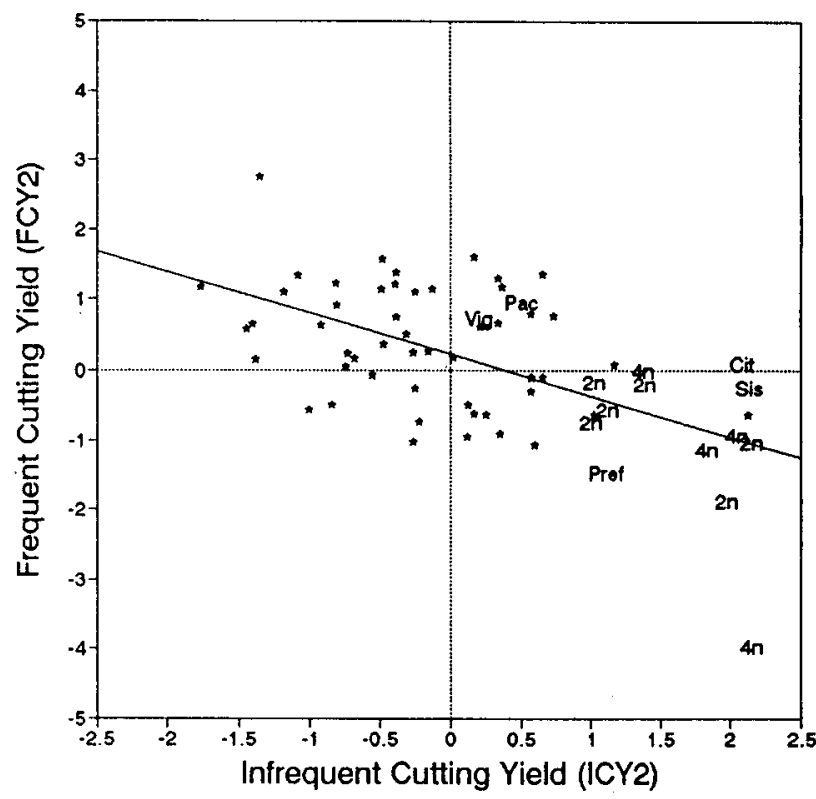

Fig 1. Relationship between the standardized yield under contrasting cutting frequencies among: (a) diploid (2n) or tetraploid (4n) varieties; (b) progenies ( ${ }^{*}$ ).

magnitude for progenies under both cutting frequencies. The variations of yield among progenies covered a much more extended range than varieties and controls, which were typically characterized by high yield under infrequent cutting and, although not so clear-cut, low yield under frequent cutting.

The analysis of morphogenetic traits revealed 2 groups of varieties, leaf size or elongation rate, which were significantly different among ploidy levels, and traits associated with leaf appearance which were only significant between genotypes within ploidy (tables I and II). Only the number of growing leaves (NGL) remained stable among genotypes and ploidy levels, ie little more than one leaf per tiller (1.32) was steadily growing at any one time on average. The ploidy level had a strong effect at the tiller scale: DMW was significantly higher for tetraploids $(1.61 \mathrm{~g})$ than for diploids $(1.05 \mathrm{~g})$ despite the error coefficient of variation being high. Moreover, polyploidization increased significantly the leaf elongation rate (LER) from 13.1 to $14.4 \mathrm{~mm} / \mathrm{d}$ (considering that the mean daily temperature during the experiment was $12^{\circ} \mathrm{C}$ ) and consequently, the adult leaf length (ALL) from 198 to $228 \mathrm{~mm}$. Phyllochron (PHY) and duration of leaf elongation (LED) were not affected by ploidy but a significant genotype effect was found within ploidy for both traits. On average, one leaf appeared every $143^{\circ} \mathrm{C} \cdot \mathrm{d}$ (ie $11.9 \mathrm{~d}$ ), which is slower than the $110^{\circ} \mathrm{C} \cdot \mathrm{d}$ found by Davies (1971). Once appeared, leaves grew for $186^{\circ} \mathrm{C} \cdot \mathrm{d}$ (ie $15.5 \mathrm{~d}$ ) before the ligule emerged from the sheath. PHY and LED ranged from 10.7 to $12.9 \mathrm{~d}$ and from 14.3 to $16.6 \mathrm{~d}$, respectively. As tillers were scored 3 times a week for estimating the morphogenesis rate, these genotypic variations, although significant, have no real practical value. Finally, no significant difference of the tiller density estimate (TD) occurred between levels of ploidy partly because most of the genetic variability was found between genotypes within ploidy as for yield under frequent cutting (FCY1).

Within-ploidy genotypic correlations between traits showed a strong relationship between ALL and DMW as expected (table III), and a negative relationship between PHY and LER already reported in tall fescue (Zarrough et al, 1984). PHY and LED appeared closely correlated, which could explain the stability of NGL among genotypes and ploidies as NGL was estimated as the ratio LED/PHY. However, NGL finally appeared more dependent on PHY than on LED, and negatively correlated. No relationship was found between PHY and TD although phyllochron determines the rate of tiller site production. Concerning yield, the results obviously showed that the morphogenetic traits recorded on varieties were never significantly correlated with yield under either cutting frequency and that only the tiller density was associated with yield under frequent cutting. 
Table III. Within-ploidy genotypic correlations between morphogenetic traits and yield under contrasting cutting frequencies.

\begin{tabular}{|c|c|c|c|c|c|c|c|c|c|}
\hline & $A L L$ & $N G L$ & LED & $L E R$ & PHY & $D M W$ & $T D$ & $F C Y 1$ & $I_{1 C Y}$ \\
\hline ALL & 1000 & & & & & & & & \\
\hline NGL & -263 & 1000 & & & & & & & \\
\hline LED & 382 & -118 & 1000 & & & & & & \\
\hline LER & 471 & 210 & -526 & 1000 & & & & & \\
\hline PHY & 412 & $-563^{*}$ & $883^{* \star}$ & $-552^{*}$ & 1000 & & & & \\
\hline DMW & $811^{\star \star *}$ & 124 & 278 & 442 & 139 & 1000 & & & \\
\hline TD & 126 & 13 & -84 & 86 & -55 & 263 & 1000 & & \\
\hline FCY1 & -18 & 56 & -45 & 249 & -77 & 158 & $703^{* *}$ & 1000 & \\
\hline ICY1 & 63 & -513 & 158 & -290 & 322 & -130 & -177 & $-721^{* *}$ & 1000 \\
\hline
\end{tabular}

Coefficients of correlation are significant at $P<0.05(*)$ and $P<0.01\left(^{* *}\right)$.

A principal components analysis indicated the overall relationships between morphogenetic traits and yield under different managements including both ploidy and genotype effects. On the coefficient of correlation circle (fig 2), the first component which explained $41 \%$ of the total variation, opposed tiller density (TD) and traits associated to leaf size or elongation rate (ALL, LER, DMW). Opposition between PHY and NGL defined the second component accounting for $26 \%$ of the total variation. The additional varieties (FCY1 and IFY1) were diagonally opposed in the diagram and illustrated that the morphogenetic approach on spaced plants did not accurately explain the adaptation to a given defoliation fre- quency as far as productivity in sward conditions is concerned. However, yield under frequent cutting seemed more associated with morphogenetic traits than yield under infrequent cutting. The range of varieties in the diagram confirmed the analysis of variance. The first component separated varieties into ploidy levels (fig 2). Tetraploids had, on average, higher ALL, LER and DMW than diploids which tended to counterbalance a low potential of leaf elongation by a higher tiller density associated with an increase of yield under frequent cutting. Variation along the second component differentiated only genotypes, regardless of ploidy level, according to PHY and NGL and independently of yield under either cutting frequency.

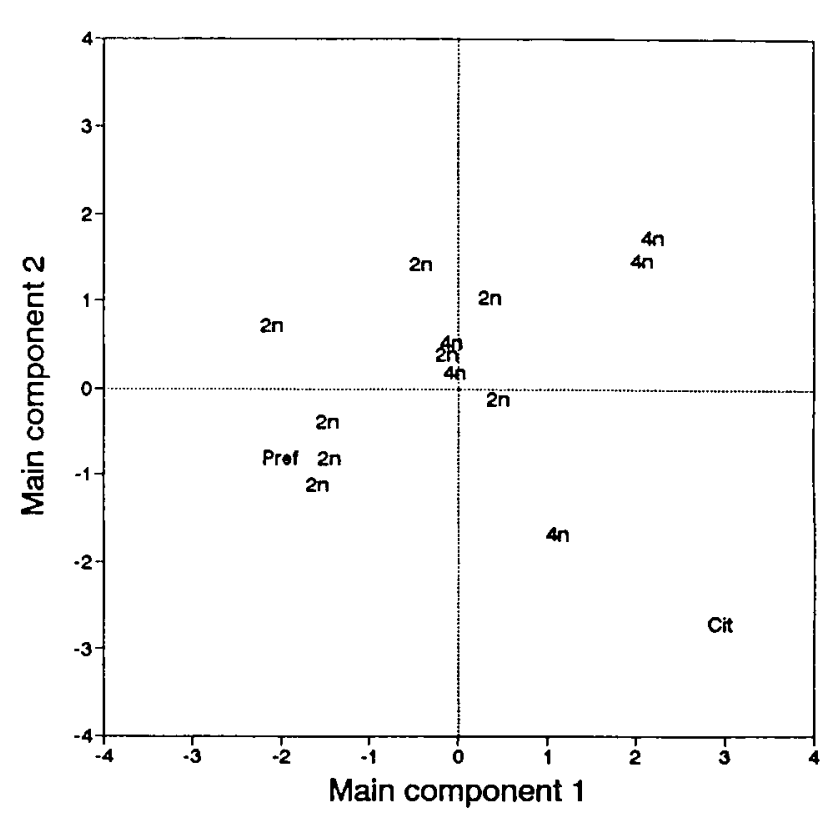

Fig 2. Principal component analysis on morphogenetic traits and tiller density in frequently cut plot using yield undercontrasting cutting frequencies as additional variates *: (left) diagram of the coefficient of correlation of traits with the 2 first principal components; (right) diagram of 13 varieties either diploid $(2 n)$ or tetraploid $(4 n)$ and 2 controls ('Preference' and 'Citadel'). 


\section{DISCUSSION}

Among the morphogenetic traits surveyed, only the variations related to elongation rate and leaf size were found significant emphasizing the effect of ploidy. The effect of polyploidization on the growth of grasses is well known. On average, tetraploids have larger and thicker leaves and are supposed to have a slower development (Hagberg and Åkerberg, 1961) and tillering rate (Castle and Watson, 1971) than diploids. Neuteboom et al (1988) reported that the slow tillering rate of the cultivar 'Condesa' resulted from a longer phyllochron and a lower rate of tiller bud appearance. However, no significant effect of ploidy was recorded from morphological traits related to chronological events such as PHY and LED, although the tiller density of tetraploid varieties tended to be lower than of diploids. The results suggested that tiller density could be also controlled by within-plant trophic competition or environmental interactions in the sward and not only by direct genetic effect of morphogenesis. Light quality and quantity penetrating through the canopy is affected by the sward growth itself. Shading and changes in red/far-red ratio control the tillering rate (Derigibus et al, 1983; Casal et al, 1985; Simon and Lemaire, 1987; Skinner and Nelson, 1992), and so the tillering process might stop earlier in tetraploid swards than in diploid ones. According to Neuteboom et al (1992), tiller persistency is improved in new tetraploid varieties and can compensate for the slow tillering rate, which allows a better tiller density.

Yield was obviously decreased by strong intensive and frequent cutting for both progenies and varieties. Frequent defoliation reduces light interception, level of metabolic reserve, mineral and water uptake and affects consequently primary productivity (Korte and Harris, 1987). No significant direct correlation between yield under either cutting frequency and morphogenetic traits was indicated among varieties. It is more important that an overall negative genotypic correlation of yield between the 2 cutting frequencies was found and that yield, at least under frequent cutting, was associated to the morphogenetic traits which discriminated between the 2 levels of ploidy. It is suggested therefore that small-sized varieties such as diploids would maintain more efficiently a higher residual leaf area index than large-sized tetraploid varieties, through optimum tiller density, when defoliation frequency increased, which allowed a higher rate of regrowth of the sward (King et al, 1979; Zarrough and Nelson, 1980). No expected positive relationship was found among varieties between leaf size or elongation rate and yield under infrequent cutting as was previously reported by Cooper and Edwards (1961), Rhodes and Mee (1980), and Nelson and Sleper (1981).

A possible explanation for the lack of expected correlations found in this paper could lie in the low variability of the morphogenetic traits of varieties within either ploidy, which can also be related to their ability to yield more under infrequent than under frequent cutting when compared with progenies. As high yield under infrequent cutting is still an important objective in forage breeding, it could be assumed that breeding methods, although independent, made leaf morphogenesis of varieties convergent by preferential selection of long-leaved genotypes. Thus, as the ploidy effect recorded among varieties seemed to suggest, a more clear-cut effect of the leaf morphogenesis on yield under a given management should be expected from highly variable natural populations.

Whatever the assumption, it appeared clearly that a potentially high productivity under frequent cutting in perennial ryegrass seemed to be systematically counterselected by forage breeders, probably in direct relation to the standard procedure of assessment of varieties applied in the official trials. As the relationship of yield between both cutting frequencies was not so close, this paper has provided some experimental evidence that breeding for flexible management could also be an alternative objective to selection for specific use, as was pointed out by Hayward (1979). In this respect, using tiller density in frequently cut plots could be of some help in assessing productivity of varieties under frequent cutting. However, a morphogenetic trait has still to be identified as a selection criterion for management adaptation of breeding. Further investigations in this objective would therefore require us to return to a more variable plant material and follow a quantitative genetics approach of the variability of leaf morphogenesis components under spaced conditions.

\section{REFERENCES}

Aldrich DTA, Elliot CS (1974) A comparison of the effects of grazing and of cutting on the relative herbage yields of six varieties of perennial ryegrass (Lolium perenne). In: Proc XII.Int GrassI Congr, Moscow, 11-15 
Allerit R (1986) Espèces fourragères pérennes: progrès réalisés depuis 25 ans, appréciés à travers l'expérimentation officielle. Fourrages 107, 17-33

Boonman JG (1989) La sélection des graminées après l'an 2000. Prophyta 8, 31-35

Casal JJ, Deregibus VA, Sanchez RA (1985) Variations in tiller dynamics and morphology in Lolium perenne Lam. Vegetative and reproductive plants as affected by differences in red/far-red irradiation. Ann Bot 56, 553-559

Castle, Watson (1971) A comparison between a diploid and a tetraploid variety of perennial ryegrass for milk production. J Agric Sci 77, 69-76

Charmet G, Balfourier F, Bion A (1990) Agronomic evaluation of a collection of French perennial ryegrass populations: multivariate classification using genotype $x$ environment interactions. agronomie 10 , 807-823

Cooper JP, Edwards KJR (1961) The genetic control of leaf development in Lolium. 1. Assessment of genetic variation. Heredity $16,63-82$

Davies A (1971) Changes in growth rate and morphology of perennial ryegrass swards at high and low nitrogen levels. J Agric Sci 77, 123-134

Davies A (1977) Structure of the grass sward. In: Proc Int Meet Animal Production from Temperate Grassl, Dublin, Ireland, 36-44.

Deregibus VA, Sanchez RA, Casal JJ, Trlica MJ (1983) Tillering responses to enrichment of red light beneath the canopy in humid natural grassland. $J$ Appl Ecol 22, 199-206

Hagberg A, Åkerberg E (1961) Mutations and polyploidy in plant breeding (A Bonnier, ed), Stockholm

Harris W (1978) Defoliation as a determinant of the growth, persistence and composition of pasture. $\mathrm{In}$ : Plant Relation in Pasture (JR Wilson, ed), CSIRO, 67-85

Hayward MD (1979) Genetic stress in ryegrass in breeding for response to management. In: Proc $X X$ th Meet Fodder Crops Section of Eucarpia, Perugia, Italy, 137-143

King J, Lamb WIC, McGregor MT (1979) Regrowth of ryegrass swards subject to different cutting regimes and stocking densities. Grass For Sci 34, 107-118

Korte CJ, Harris W (1987) Effects of grazing and cutting. In: Ecosystems of the World (RW Snaydon, ed), Elsevier, 71-79

Lemaire G (1988) Sward dynamics under different management programmes. In: Proc XII Gen Meet European Grassld Fed, Dublin, Ireland, 7-23

Mazzanti A, Lemaire G (1994) Effect of nitrogen fertilisation on herbage production of tall fescue swards continuously grazed by sheep: 2 . Consumption and efficiency of herbage utilisation. Grass For Sci (in press)

Nelson CJ, Sleper DA (1981) Using leaf area expansion rate to improve yield of tall fescue. In: Proc XIV Intern Grassid Cong, Lexington, USA, 413-416

Neuteboom JH, Lantinga EA, Wind K (1988) Tillering characteristics of diploid and tetraploid perennial ryegrass. In: Proc XII Gen Meet European GrassI Fed, Dublin, Ireland, 498-503

Neuteboom JH, Lantinga EA, Van Loo EN (1992) The use of frequency estimates in studying sward structure. Grass For Sci 47, 358-365

Rhodes I (1969) The relationship between productivity and some components of canopy structure in ryegrass (Lolium spp). I. Leaf length. J Agric Sci 73, 315-319

Rhodes I (1971) The relationship between productivity and some components of canopy structure in ryegrass (Lolium spp). II. Yield, canopy structure and light interception. J Agric Sci 77, 283-292

Rhodes I (1973) The relationship between productivity and some components of canopy structure in ryegrass (Lolium spp). III. Spaced plant characters, their abilities and relationship to sward yield. $J$ Agric Sci $80,171-176$

Rhodes I (1975) The relationship between productivity and some components of canopy structure in ryegrass (Lolium spp). IV. Canopy characters and their relationship with sward yields in some intra-population selections. J Agric Sci 77, 283-292

Rhodes I, Mee SS (1980) Changes in dry matter yield associated with selection for canopy characters in ryegrass. Grass For Sci 35, 35-39

Simon JC, Lemaire G (1987) Tillering and leaf area index in grasses in the vegetative phase. Grass For Sci 42, 373-380

Skinner RH, Nelson CJ (1992) Estimation of potential tiller production and site usage during tall fescue canopy development. Ann Bot 70, 493-499

Snyder H, Seo S, Rademacher IF, Kuhbauch W (1990) Spatial distribution of growth rates and epidermal cell lengths in the elongation zone during leaf development in Lolium perenne L. Planta 181, 423-431

Van Wijk APJ, Reheul D (1990) Achievements in fodder crops breeding in maritime Europe. In: Proc 16th Meet Fodder Crops Sect Eucarpia, Wageningen, The Netherlands, 13-18

Zarrough KM, Nelson CJ (1980) Regrowth of genotypes of tall fescue differing in yield per tiller. Crop Sci $20,541-544$

Zarrough KM, Nelson CJ, Sleper DA (1984) Interrelationships between rates of leaf appearance and tillering in selected tall fescue populations. Crop Sci $24,565-569$ 